\title{
The Concept of Qath 'i and Zhanni and Its Implication to Religious Behavior among Muslim Communities in Lombok
}

\author{
Lalu Supriadi bin Mujib ${ }^{1}$, Khairul Hamim², Setiyawan Bin Gunardi ${ }^{3}$
}

\begin{abstract}
The Concept of Qath 'i and Zhanni and Its Implication to Religious Behavior among Muslim Communities in Lombok. The difference in understanding of the concepts of qath $i$ and zhanni is the root of the problem that causes conflict among Muslims, especially among the Salafi and non-Salafi communities. This study aims to determine the concepts of qath ' $i$ and zhanni, the response of the Salafi and non-Salafi communities to the concepts, and its implications in shaping their religious behavior. This study used a descriptive qualitative approach with a case study method and a field research design. Collecting data using observation, interview, and documentation techniques. The data analysis technique uses the description, interpretation, criticism, and conclusion stages. The results of this study indicate that the concepts of qath $i$ and zhanni are used by ulama Ushul Fiqh to analyze legal texts from the linguistic aspect that are used as standards for assessing the legality and validity of the law. Salafi and Non-Salafi communities agree on qath ' $i$ as an inviolable conception, whereas zhanni is not considered. Methodological differences in identifying the concept of qath ' $i$ and zhanni areas have implications for religious behavior among Muslims in Lombok, Mataram. By using a textual approach and ignoring the contextual approach, Salafis consider laws that are still in a clear area as qath $i$. On the other hand, Non-Salafis use textual and contextual approaches to conclude that the law that is still being debated is zhanni.
\end{abstract}

Keywords: The concept of qath ' $i$ and zhanni, Ijtihad, Muslim in Lombok.

\begin{abstract}
Abstrak: Konsep Qath $i$ dan Zhanni dan Implikasinya pada Perilaku Beragama di Komunitas Muslim di Lombok. Perbedaan pemahaman terhadap konsep qath ' $i$ dan zhanni merupakan akar permasalahan yang menyebabkan konflik di kalangan umat Islam khususnya di kalangan komunitas salafi dan non-salafi di Lombok. Penelitian ini bertujuan untuk mengetahui konsep qath $i$ dan zhanni, respon komunitas Salafi dan non-Salafi terhadap konsep itu, serta implikasinya dalam membentuk perilaku beragama mereka. Penelitian ini menggunakan pendekatan kualitatif deskriptif dengan metode studi kasus dan desain penelitian lapangan. Pengumpulan data menggunakan teknik observasi, wawancara, dan dokumentasi. Teknik analisis data menggunakan tahapan deskripsi, interpretasi, kritik, dan kesimpulan. Hasil penelitian ini menunjukkan bahwa konsep qath $i$ dan zhanni digunakan oleh ulama Ushul Fiqh untuk menganalisis teks hukum dari aspek kebahasaan yang digunakan sebagai standar untuk menilai legalitas dan validitas hukum. Komunitas Salafi dan Non-Salafi
\end{abstract}

\footnotetext{
${ }^{1}$ Postgraduate Program, UIN Mataram, Lombok, Indonesia

${ }^{2}$ Faculty of Sharia and Law, UIN Mataram, Lombok, Indonesia

${ }^{3}$ Faculty of Syariah and Law Universiti Sains Islam Malaysia (USIM), Bandar Baru Nilai 71800 Nilai Negeri Sembilan Malaysia

E-mail: '1alusupriadi@uinmataram.ac.id, ${ }^{2}$ khairulhamim@ymail.com, ${ }^{3}$ setiyawan@usim.edu.my
} 
menyepakati qath ` $i$ sebagai konsepsi yang tidak bisa diganggu gugat, sedangkan zhanni tidak dianggap demikian. Perbedaan metodologi dalam mengidentifikasi konsep qath $i$ dan zhanni berimplikasi pada perilaku beragama di kalangan umat Islam di Lombok, Mataram. Dengan menggunakan pendekatan tekstual dan mengabaikan pendekatan kontekstual, para salafi menganggap hukum yang berada dalam wilayah yang tidak jelas sebagai qath'i. Di sisi lain, Non Salafi menggunakan pendekatan tekstual dan kontekstual untuk menyimpulkan bahwa hukum yang masih diperdebatkan adalah zhanni.

Kata kunci: Konsep qath $i$ dan zhanni, Ijtihad, Muslim di Lombok.

\section{Introduction}

The reality of social life among Muslims live in Lombok shows that they have different forms of religious practice between Salafi and NonSalafi communities. The differences often influenced the sharp friction at the grass-root level and even the conflict among themselves which is showed in several violent cases, vandalism, and anarchist actions. These are like the research result conducted by Saparudin and Emawati ${ }^{1}$ who identified 14 conflicts that occurred in Lombok. ${ }^{2}$ This conflict also indicates that there are various problems among Muslims in understanding and practicing their religious teachings. Whereas Islamic teachings are aimed to make their life safe, peaceful, serene, mutual respect, living together, and respect one to each other, like emphasized in the al-Shatibi's opinion that the purpose of religious life is to create benefits for all human beings. ${ }^{3}$

${ }^{1}$ Saparudin Saparudin and Emawati, 'Masjid dan Fragmentasi Sosial: Pencarian Eksistensi Salafi di Tengah Mainstream Islam di Lombok, Research Report in 2018 (Mataram: LP2M UIN Mataram), p. $4 \& 24$.

2 These conflicts are included by the attack and destruction of the Ihya 'As-Sunnah Islamic Boarding School facilities which adhere to Salafi beliefs in the area of Repok Gapuk, Sekotong Tengah Village, Sekotong Tengah District, and West Lombok District. The conflict was also triggered by the differences of religious and customary understanding between the community and the Salafi groups. A similar case occurred in Gelogor and Sesela Villages where thousands of Sesela residents attacked the Salafi Islamic Boarding School Foundation Ubay Bin Ka'ab led by Fathul Aziz in Kebon Lauk hamlet. The invasion was triggered by the differences in understanding and traditions regarding talkin during the burial of the dead (jenazah) and qunut during Fajr

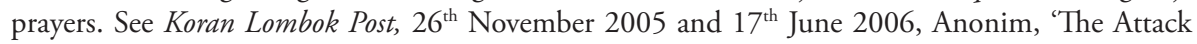
of Salafi Group into Mesanggok Village Gerung District.', Tabloid Perspektif, 1 March 2009.

${ }^{3}$ Abu Ishak al-Syathibi, Al-Muwafaqat Fi Ushul al-Syariah (Beirut: Dar al-Kutub alIlmiyah), p. 35. 
The various factors that became to the conflict among the Muslims in Lombok are inseparable from the intellectual discourse between the classical and contemporary Ushul Fiqh scholars regarding the status of qath'i (definite/uninterpretable) and zhanni (indefinite/interpretable) as theories and methodologies in formulating and exploring Islamic law (ijtihad). The classical Ushul Fiqh scholar argues that the Quran and the Hadith are qath'i al-tsubut wa al-wurud (definite in its existence and revelation), and some of their texts are qath'i al-dalalah (definite argument) and some of them are zhanni al-dalalah (indefinite argument). Based on the reason, the interpretation of the Quranic verses falls into the qath'i (definite) category which is put in the final and inviolable conceptions. Meanwhile, regarding ijtihad, they assume that some of the verses included into the category of zhanni al-dalalah (indefinite argument) like stated by al-Samarqandi, ${ }^{4}$ al-Taftazani, ${ }^{5}$ and al-Syairazi. ${ }^{6}$ This opinion was also followed by several academicians, like Asep Arifin, ${ }^{7}$ Saifuddin Sa'dan, ${ }^{8}$ Romli SA, ${ }^{9}$ Moh. Mufid, ${ }^{10}$ and Muslim. ${ }^{11}$

In contrast, some contemporary scholars and academicians such as Ibn 'Ashur, ${ }^{12}$ Jasser Auda, ${ }^{13}$ and Mohammad Arkoun ${ }^{14}$ criticized the concepts of qathi and zhanni in line of linguistic aspect, because the

4 'Alauddin al-Samarkandi, Mîzan Al-Ushûl Fî̀ Natâij al-'Uqûl, 2nd edn (Kairo: Dar al-Turats, 1997).

${ }^{5}$ Saduddin al-Taftazani, Syarh Al-Talwîh 'Ala al-Taudlìh (Beirut: Dar al-Fikr, 1424), I.

${ }^{6}$ Abu Ishaq al-Syairazi, Al-Luma' Fî Ushûl al-Figh, 3rd edn (Kairo: Mushthafa al-Babi al-Halabi, 1377).

${ }^{7}$ Asep Arifin, 'Aplikasi Dalil Qath'i dan Zhanni dalam Pertimbangan Subyek dan Tujuan Hukum', Jurnal Ahkam 13, Number 1 (2013): 89-98.

${ }^{8}$ Saifuddin Sa'dan, 'Ijtihad Terhadap Dalil Qath'i dalam Kajian Hukum Islam', Samarah: Jurnal Hukum Keluarga Dan Hukum Islam 1, Number 2 (2017): 479-90.

${ }^{9}$ Romli SA Romli SA, 'Konsep Qath'iy-Zhanniy serta Implikasinya dalam Istinbath Hukum', Jurnal Intizar 21, Number 1 (2015): 147-63.

${ }^{10}$ Moh. Mufid, 'Qath'i dan Zhanni dalam Pemikiran Islam; Memahami Teks dan Konteks Secara Proporsional', Jurnal Al Hikmah 15, Number 2 (2014): 232-50.

${ }^{11}$ Muslim Muslim, 'Qath'i-Zhanni Al-Syathibi dalam Pembentukan Hukum Islam', Jurnal Wasathiyah 2, Number 1 (2018): 97-108.

${ }^{12}$ Muhammad Tahir Ibnu Asyur, Maqashid Al-Syariah Al-Islamiyah (Cairo and Beirut: Dar al-Kitab al-Mishri and Dar al-Kitab al-Lubnani, 2011), 5.

${ }^{13}$ Retna Gumanti, 'Maqasid Al-Syariah Menurut Jasser Auda: Pendekatan Sistem dalam Hukum Islam', Jurnal Al-Himayah 2, Number 1 (2018): 97-118.

${ }^{14}$ Mohammad Arkoun, The Politics of Islamic Revivalism (Editor) Shireen T. Hunter (Bloomington: Indiana University Press, 1988), pp. 182-83. 
excessive attention to the linguistic aspect would lead to a literalist and textual understanding, and also ignoring the core purpose and substance of Islamic law. According to Arkoun, the dichotomy of the verses of alQuran being qathi and zhanni means limiting the content of the meaning even though it has many interpretations. This opinion was followed by several academicians in their research, including Umi Cholifah, ${ }^{15}$ Ratu Haika, ${ }^{16}$ Firdaus, Laode Ismail Ahmad and Syamsidar. ${ }^{17}$ Based on the two views above, it is clear that the Muslim scholars are divided into two schools in responding to the concepts of qath'i and zhanni, like mentioned in Abdullah Saed's term that the first group is called the traditionalist legalists whose emphasis is talking about the understanding of laws that developed and interpreted by the classical Muslim scholars. The second group is called the progressive ijtihadis which try to reconstruct Islamic law so that it can answer the problems among modern society needs. ${ }^{18}$

Furthermore, several academicians such as Zunly Nadia, ${ }^{19}$ Muhammad Imdad Robbani, ${ }^{20}$ Ubaidillah, ${ }^{21}$ and Faizah ${ }^{22}$ analyzed the normative characters to identify Salafi and Non-Salafi communities. Zunly Nadia, in her research, shows that the Salafi as a community is a contemporary religious thought movement that has certain forms

${ }^{15}$ Umi Cholifah, 'Membumikan Qath'I dan Zhanni; Konsep Absolut dan Relativitas Hukum', Jurnal An-Nuha 4, Number 2 (2017): 141-47.

${ }^{16}$ Ratu Haika, 'Konsep Qath'i dan Zhanni dalam Hukum Kewarisan Islam', Jurnal Mazahib 15, Number 2 (2016): 183-95.

${ }^{17}$ Laode Ismail Ahmad and Syamsidar, 'Rekonstruksi Teks-Teks Hukum Qath'i dan TeksTeks Hukum Zhanni; Meretas Jalan Menuju Pendekatan Tekstual-Kontekstual', Asy-Syir'ah; Jurnal Ilmu Syariah dan Hukum 49, Number 2 (2015): 233.

${ }_{18}$ According to Abdullah Saed, Muslim thinkers can be categorized into six groups, such as the legalist traditionalist, the theological puritans, the political Islamists, the Islamist extremists, the secular Muslims, and the progressive ijtihadis. (See Abdullah Saed, Islamic Thought An Introduction (London and New York: Routledge, 2006), pp. 142-50.

19 Zunly Nadia, 'Perilaku Keagamaan Komunitas Muslim Di Indonesia: Pemahaman Hadis Dalam NU dan Komunitas Salafi Wahabi Di Indonesia’, Jurnal Living Hadis, 2.2 (2017), 141-77 (pp. 141-77).

${ }^{20}$ Nadia, 'Perilaku Keagamaan Komunitas Muslim di Indonesia: Pemahaman Hadis dalam NU dan Komunitas Salafi Wahabi di Indonesia', 245-76.

${ }^{21}$ Ubaidillah Ubaidillah, 'Global Islam dan Pengaruhnya di Indonesia', Jurnal Thaqafiyyat 13, Number 1 (2012): 35-48.

${ }^{22}$ Faizah Faizah, 'Pergulatan Teologi Salafi dalam Mainstream Keberagamaan Masyarakat Sasak', Jurnal Ulumuna IAIN Mataram 16, Number 2 (2012): 375-402. 
and patterns of thought and often collides with mainstream Islam in its religious practice. Meanwhile, Non-Salafis are communities who are practicing their religious norms very open with the harmonization between local culture and traditions through Islamic teachings, and even incorporate them into local wisdom that must be preserved. ${ }^{23}$ Muhammad Imdad Robbani identified the nature and character of Salafis who tend to understand religion too tightly, textual literalists, exclusive, truth claims, do not acknowledge the scholarly authority of scholars outside them, easily misleading Muslims who have different understandings from them. In this, Ubaidillah concluded that the Salafi movement is a more fundamental, revivalist, or transnational religious stream.

According to Faizah, the Salafi community in many ways is often misjudges the beliefs or traditions adhered to within the local community and assumes them occurred bid'ah (heresy) about what they have been carried out from generation to generation. Some academicians, in previous studies, have conducted a lot of research about the Salafis from the aspect of the normative character to distinguish them from Non-Salafis thought. The other, like Moh. Nashiruddin ${ }^{24}$ and Abd. Rachman Assegaf ${ }^{25}$ examine it from the aspect of its ability to maintain the pure Islamic values in the globalization mindset. Other academicians, like Juan Carlos Antunez ${ }^{26}$ have studied it from the political aspect, and also Muhd Imran Abd Razak $^{27}$ and Najwan Saada ${ }^{28}$ have studied it from the educational aspect.

${ }^{23}$ Nadia, 'Perilaku Keagamaan Komunitas Muslim di Indonesia: Pemahaman Hadis dalam NU dan Komunitas Salafi Wahabi di Indonesia’, 141-77.

${ }^{24}$ Muh Nashirudin, 'Interaksi Simbolis Pondok Pesantren Salafi dan Masyarakat', Epistemé: Jurnal Pengembangan Ilmu Keislaman, 12.1 (2017), 141-67 <https://doi.org/10.21274/ epis.2017.12.1.141-167>.

${ }^{25}$ Abd Rachman Assegaf, 'Gerakan Transnasional Islam dan Globalisasi Salafi di Islamic Center Bin Baz Yogyakarta', Millah: Jurnal Studi Agama, 0.2 (2017), 147-72 <https://doi. org/10.20885/millah.vol16.iss2.art1>.

${ }^{26}$ Juan Carlos Antunez, 'Salafism: From a Religious Movement to a Political Force', Revista de Estudios En Seguridad Internacional 3, Number 1 (2017): 11-42.

${ }^{27}$ Muhd Imran Abd Razak et al., 'Salafi Jihad's Version and Coercion to World Peace: An Islamic Educational Perspective', International Journal of Academic Research in Business and Social Sciences 7, Number 12 (2017): 1265-80.

${ }^{28}$ Najwan Saada, 'The Theology of Islamic Education from Salafi and Liberal Perspectives', The Official Journal of the Religious Education Association, 2018, 1-13 (pp. 1-13) <https://doi. org/DOI: 10.1080/00344087.2018.1450607>. 
The reality of social life among Muslims living in Lombok shows that they have different forms of religious practice between Salafi and non-Salafi communities. These differences often result in sharp friction at the grassroots level and even conflicts between themselves which have been proven in several cases of violence, vandalism, and anarchist actions. This is as shown by the results of Saparudin and Emawati's research which identified 14 conflicts occurring in Lombok. This conflict also shows the existence of various problems among Muslims in understanding and practicing their religious teachings. Whereas Islamic teachings aim to make their lives safe, peaceful, peaceful, mutual respect, living together, and respecting each other, as emphasized by al-Shatibi that the purpose of religious life is to create benefits for all humans.

The various factors causing conflict among Muslims in Lombok are inseparable from the intellectual discourse between classical and contemporary Ushul Fiqh scholars regarding the status of qath'i and zhanni, as theories and methodologies in formulating and deepening Islamic law (ijtihad). The classical scholars of Ushul Fiqh argue that the Quran and Hadith are qathi al-tsubut wa al-wurud (definite in terms of text and source), some of the texts are qath'i al-dalalah (textually definite) while others are zhanni al-dalalah (textually indefinite/interpretable). Based on the reason, the interpretation of the verses of the Qur'an is included in the category of qath'i (definite) which is included in the final and inviolable conception. As for ijtihad, they consider that some verses fall into the category of zhanni al-dalalah (indefinite/interpretable argument), as stated by al-Samarqandi, al-Taftazani, and al-Syairazi. This opinion was also shared by several academics, such as Asep Arifin, Saifuddin Sa’dan, Romli SA, Moh. Mufid, and Muslim.

On the other hand, some contemporary scholars and academicians, namely Ibn 'Ashur, Jasser Auda, and Mohammad Arkoun criticized the concept of qath'i and zhanni in the linguistic aspect. According to them, excessive attention to linguistic aspects will lead to literal and textual understanding, and also ignore the core purpose and substance of Islamic law. According to Arkoun, the dichotomy of the verses of the Qur'an into qath'i and zhanni means limiting their meaning even though they have 
many interpretations. This opinion was followed by several academicians in their research, including Umi Cholifah, Ratu Haika, Firdaus, Laode Ismail Ahmad, and Syamsidar. Based on the two views above, it is clear that the scholars in addressing the concepts of qath ' $i$ and zhanni are divided into two schools of thought, as stated in Abdullah Saed's term that the first group is called the strict traditionalist legalists whose emphasis is on understanding the law developed and interpreted by classical Muslim scholars. The second group is the progressive ijtihadis which seeks to reconstruct Islamic law so that it can answer the needs of modern society.

Based on the results of the author's investigation of existing literature, research on the concepts of qath ' $i$ and zhanni and its implications to the religious behavior of Salafi and non-Salafi communities in Lombok can be said to be very rare, if not nonexistent. Whereas the understanding of the concepts of qath $i$ and zhanni has penetrated religious practice and subsequently forms religious behavior which also serves as a basis of differences and conflicts that have occurred between them to date. This study aims to complement the shortcomings of existing studies, especially regarding the concept of qath $i$ and zhanni in the perspective of Islamic law, the response of the Muslim community in Lombok to these concepts, including the implications of understanding the concept in shaping the religious behavior of the community.

Religious behavior is the act, ways of doing, or actions of a person in daily activities that cannot be separated from various activities related to his religious beliefs. ${ }^{29}$ Religious behavior is not only manifested in the form of daily activities that appear real but also everything that is not visible, namely in a person's heart. According to Glock and Stark, as quoted by Ancok and Suroso, there are five dimensions of diversity, namely belief (ideological), religious practice (ritualistic), experience or reward (experiential), practice (consequential), and religious knowledge (intellectual). ${ }^{30}$ In this context, both the Salafi and non-Salafi communities in Lombok are influenced by their ideology and intellectual capacity

${ }^{29}$ Djamaludin Ancok and Fuad Nashori Suroso, Psikologi Islam: Solusi Islam Atas ProblemProblem Psikologi (Yogyakarta: Pustaka Pelajar, 2004), p. 77.

${ }^{30}$ Ancok and Fuad Nashori Suroso, ....77. 
which is manifested in the form of religious practice which is then transformed into their life behavior.

The Salafi community analyzes the legal problems with a literaltextual approach to place their legal propositions that are. In contrast, the Non-Salafi community is using a textual and contextual approach in accordance with time and space.

Based on the description above, it can be said that the genealogical differences and conflicts between them today are caused by differences in understanding of the concepts of qath $i$ and zhanni which are used to linguistically analyze the Qur'an and Hadith texts. Salafi communities analyze legal problems with a literal-textual approach by placing their legal arguments, namely qath $i$ dan zhanni. The Non-Salafi community, on the other hand, uses a textual and contextual approach according to time and space.

\section{Method}

This research is classified as qualitative research through the case study method. The characteristics of qualitative research according to Sanafiah Faisal's view as quoted by David Williams, include providing an explanation of complex rules and interactions in society, identifying new information, demanding rich descriptions and conclusions about the context. ${ }^{31}$

The methods used to collect data in this study are in-depth interviews, observation, and documentation. In the interview activity, researchers used an unstructured interview method aimed at seeking further and in-depth information about the understanding of Muslims in Lombok about the concepts of qath $i$ and zhanni and their implications to religious behavior among Muslims in the city. Observations were made to determine the activities of socio-economic, socio-religious, educational, and social institutions as well as the religious behavior of Muslims in Lombok. Meanwhile, the documentation method is carried out by tracing data sources related to the concepts of qath $i$ and zhanni which are written

${ }^{31}$ Sanafiah Faisal, Penelitian Kualitatif: Dasar-Dasar dan Aplikasi (Malang: YA3, 1990), p. 22. 
in both classical and contemporary ushul fiqh and fiqh books.

Selection of informants using purposive sampling method which is based more on competence, not based on representation. The selected informants as the key informants involve religious figures such as Tuan Guru Haji (TGH), Kiyai or Ustadz, and community leaders who are considered competent to know how they understood the concepts of qath $i$ and zhanni. Data analysis was carried out using the critical analysis method through several stages, including (1) describing ideas related to the research objectives; (2) discuss or interpret ideas; (3) criticizing ideas that have been interpreted or carried out through analytic studies, and (4) formulating conclusions. ${ }^{32}$ In this study, the concepts and theories about qath'i and Zanni will be analyzed in-depth based on classical and contemporary sources or references written by scholars. Meanwhile, to analyze social phenomena, data will be collected so that religious behavior can be identified in Salafi and non-Salafi communities based on their understanding of the concepts of qath'i and zhanni. From the two techniques, the author concludes the implications of understanding the concepts of qath ' $i$ and zhanni in religious behavior among Salafi and non-Salafi communities in Lombok.

\section{Qath $i$ and Zhanni in the Ulama Perspective}

Etymologically, the word qath $i$ comes from the basic word qatha 'a yaqtha' $u$-qath 'an, which means sharm (to make sure), ibânah (to explain), and fashl (to decide) ${ }^{33}$. It is related to a concrete object such as breaking a rope, or an abstract one such as breaking a friendly relationship. ${ }^{34}$ The use of the words is often juxtaposed with vocabulary; al-haq (truth), al-dalîl (legal basis), al-yaqîn (belief), and al-'ilm (knowledge). In this research, however, the qath $i$ and zhanni will be studied in terms of arguments

${ }^{32}$ Jujun S. Suriasumantri, Penelitian Ilmiah, Kefilsafatan, dan Keagamaan: Mencari Paradigm Kebersamaan", in Deden Ridwan (Ed). Tradisi Baru Penelitian Agama Islam Tinjauan Antar Disiplin Ilmu (Bandung: Penerbit Nuansa, 2011), 68.

${ }_{33}$ Ibnu Faris Ibnu Faris, Mu’jam Maqâyîs al-Lugah, 2nd ed., vol. 5 (Kairo: Mushthafa al-Babi al-Halabi, 1971), 101.

${ }^{34}$ Al-Ragib al-Ashfahani, Al-Mufradât fì Garî̀ al-Qur'ân, 1st ed., vol. 1 (Damaskus: Dar al-Qalam, 1412), 408. 
as legal basis, both those mentioned textually (manthûq) or contextually (mafhim) in the texts of the al-Qur'an and Hadith. Terminologically, two schools define the term qath $i$ based on their different understanding of the substance. First, the designation of meaning is not accompanied by other possible meanings. According to al-Razi, based on certainty, the term al-'ilm (knowledge) does not need to be strengthened because it is the most powerful science. If it is possible to show another meaning, even if it is far away it turns into zhanni. ${ }^{35}$ Second, the designation of meaning is not accompanied by other possible meanings that are supported by the arguments. According to al-Ghazali, if it is required that there is no possibility of indicating other meanings in the legal text, then someone cannot know the syar'i argument (the designation of the meaning is clear) because there are also many verses in the Koran and the Hadith of the Prophet Muhammad SAW that have other meanings. ${ }^{36}$

Al-Qarafi asserted that the qath $i$ argument is sometimes plagued by confusion of meaning. This then led to a difference in logic problems. Some issues have been agreed upon based on qath ' $i$ arguments but some people disagree with that agreement. For example, the statements "the universe was created" and "this nature statement was created". Both statements must be true even though there is confusion in meaning but they do not affect the substance of the dalîl (legal basis). ${ }^{37}$ This reasoning above shows how the confusion of meaning can occur.

Al-Taftazani offers a middle way by combining the two concepts. The concept of "Qath ' $i$ " is used to deny the possibility of having another meaning and sometimes denying the possibility of indicating other meanings which are supported by the argument. ${ }^{38}$ While zhanni is the antonym of qath $i$ which means assumption (guessing) or uncertain knowledge. According to the terminology, there are two possible laws but another one is stronger than the other. ${ }^{39}$ The first variable stated

${ }^{35}$ Fakhruddin Al-Razi, Al-Mahshul Fi Ilmi al-Ushul, 2nd edn (Beirut: Dar al-Kutub alIlmiyah, 1408), p. 445.

${ }^{36}$ Abu Hamid al-Gazali, Al-Mankhul fi Ta'liqat Al-Ushul (Beirut: Dar al-Fikr, 1400), 166.

${ }^{37}$ Syihabuddin al-Qarafi, Syarh Tanqîh al-Fushûl (Beirut: Dar al-Fikr, 2014), 340.

${ }^{38}$ Al-Taftazani, Syarh Al-Talwîh 'Ala al-Taudlîh, 1:18.

${ }^{39}$ Al-Syairazi, Al-Luma' fì Ushûl al-Fiqh, 48. 
by al-Taftazani can be implemented in the mubkamât verses, which are definite words to indicate the meaning of al-Qur'an and the Hadith Mutawatir; While the second concept can be implemented in the Khabar Ahâd and Qiyâs. Like the qath'i, the form of al-zhann is based on two factors: first, it is objectively placed as the strength and completeness of the argument (legal basis), and second, it is subjectively placed as the psychological condition of the soul in formulating the legal products.

In the perspective of Ushul Fiqh, seen from the level of truth and certainty of human thinking, al-ilm has a 100\% level of truth and certainty between news and reality, while al-zhann has a level of truth and certainty between news and reality is $50-90 \%$, al -syak level of truth and certainty between news and reality is $50 \%$, al-wahm, the level of truth and certainty between news and reality is $10-50 \%$, and finally, al-jahlu the level of truth and certainty between news and reality is $0 \%$. Based on this formula, it can be concluded that al-zhann is in the second position after al-'ilm (knowledge).

Furthermore, between qath $i$ and zhanni there are several similarities. The similarities are mostly related to the realm of dalîl syar ' $i$ (Islamic legal basis), which can be seen in the emergence of things that resulted from the soul and then is translated by human thought and then constitute the legal decisions or rules. it is the means by which to know sharia norm and may not occur in one case at the same time.

Whereas the difference is: knowledge (qath $\left.{ }^{\prime} i\right)$ is obtained from certainty, while zhanni is obtained from uncertainty (assumptions/ prediction). In zhanni it is possible to have other meanings that arise from arguments, whereas in qath $i$ it cannot have other meanings; Another difference is that the concept of qath $i$ has only one meaning, whereas zhanni has two or more possible meanings. People, who know something qath $i$, will understand it according to the compatibility between everything they believe and reality because it is impossible or unreasonable for someone to ascertain something clearly without his knowing very well about what happened. Conversely, people who know something zhanni do not know the suitability of the conjecture with reality. 
The proposition is very closely related to the concepts of qath ' $i$ and zhanni. Etymologically, the dalil is a concrete guide or something that gives knowledge (from not knowing to know) in an abstract meaning. According to the terminology of fiqh science, a dalil can lead a person to the demands of khabar (news) through correct observation. Meanwhile, according to logic, an argument is something that can convey someone's knowledge of the nature of something correctly.

This difference in concept can also be explained through the terminology of exact science and imprecise science. The first type is called dalil (basic law) which produces qath $i$ (true exact knowledge), such as the existence of nature and the existence of a Creator (Allah). The second is called amârah (sign) which produces zhanni (assumption or guesswork), like a cloudy sky, this indicates there will be rain even though it may not necessarily be rain because it may suddenly disappear and the sky becomes clear again. In short, understanding the dalil will result in both knowledge (qathi) and assumptions (zhanni), both of which can occupy degrees of certainty.

Furthermore, al-Samarqandi emphasized that in general the word dalîl is used to describe all knowledge obtained through feeling, news, and reason, whether it results in definite knowledge and actions or not. That is why Qiyas and Khabar Ahâd are called dalîl even though they are not qath'i. ${ }^{40}$ Several aspects distinguish dalîl from qath 'i: first, dalîl means knowing something and qath $i$ is a part of knowledge; Second, qath ' $i$ can be obtained without using dalîl but its meaning can be known through taqlid (following other people's opinions). If the conditions of the dâil are fulfilled, namely correct observation/views, it will result in an al-'ilm (knowledge) which is definite and true; third, through the correct observation, dalîl will produce knowledge that is always following reality. In contrast, qath $i$ is not always compatible with reality or sometimes is not appropriated.

${ }^{40}$ Al-Samarkandi, Mîzan al-Ushîul fì Natâij al-'Uqûl, 71. 


\section{The Dynamics of Religious Thought among Muslim Community}

The dynamics of religious thought among Muslims in Lombok, which continue to develop from time to time, have implications for the formation of religious attitudes, views, and behaviors. The religious attitudes and views referred to their perceptions related to religious values and morality, as well as in the form of religious practices and others Islam is a religion having universal and comprehensive values which are implemented in various important manifestations in various fields such as faith, sharia (figh), and morals. If there is a polarization of religious understanding, it can be divided into two categories, namely Salafi and Non-Salafi.

\section{The Salafi's Religious Thought}

In the context of Lombok, there is not certain data about when the Salafi movement was first introduced. According to Saparudin and Emawati, there are at least two reasons to explain it. First, it is based on the lack of works written about the Salafi movement in Lombok. Second, the Salafis are seen as a new reality compared to other social organizations such as NU, NW, and Muhammadiyah. ${ }^{41}$ Based on the tracking results, in 1989 Tuan Guru Husni Bagik Nyake Aikmel was believed to be the first famous Muslim figure to introduce the Salafi understanding and movement in Lombok. He is well known as a figure who grew up in the NU family from parents named Haji Abdul Manan, a respected and charismatic educator in the region. He was also spent his youth studying in Makkah, then after returning to Lombok, he was given the task of developing the Al-Manar Islamic Boarding School, which was the forerunner to the reproduction of this flow and movement.

Muhammad Imarah ${ }^{42}$ mentioned three main characteristics of the Salafi movement, namely: first, rejecting all forms of philosophical thought,

41 Saparudin and Emawati, 'Masjid dan Fragmentasi Sosial: Pencarian Eksistensi Salafi di Tengah Mainstream Islam di Lombok, Research Reports, (Mataram: LP2M UIN Mataram, 2018), p. 24', 24.

${ }^{42}$ Muhammad Imarah is the Ulama Salafi from Midang Gunung Sari Village, West Lombok, who has acted in religious teaching to the people in several places in Lombok. 
kalam, and tasawuf; second, firmly against anything considered bid'ah, (heresy), shirk and khurafat (superstition),; and third, as a continuation of the first character, the Salafis reject ijtihad bi al-rayi (reasoning) in interpreting the rationality of Islamic norms. ${ }^{43}$ Referring to this character, several manifestations appear in the form of religious beliefs and practices. The most important thing from Salafi teachings is the spirit to carry out a purification movement in understanding religious teachings to conform to the Qur'an and Sunnah of the Prophet Muhammad SAW, as well as the actions and understanding of Salafu al-Salih (pious predecessors). ${ }^{44}$ This form of purification is seen in Tuan Guru Mahsun's comment who says:

...The understanding that must be put into practice is the correct understanding or teaching that comes directly from the Prophet Muhammad, which of course cannot be wrong in educating his followers. In contrast to the opinions of scholars as scattered in the yellow book, it could be true but it could also be wrong. On this basis, the conceptions or teachings of Islam that develop in this society must be straightened out, so that they carry out their worship following what was outlined by the Prophet Muhammad SAW. ${ }^{45}$

In the field of monotheism, the Salafis return the tawheed doctrine to the understanding of salaf al-salih, namely tawhid of asma' and attribute to determine the asma' and the attributes of Allah as He has determined for Himself and has also been established by His Messenger without tamtsil (parable), takyif (matching), and ta'wil (interpretation). They forbid building graves, covering them, providing lighting, and all other forms of heresy. They also reject all forms of expression and adventures of Sufism Tariqat that have entered religion but never existed in the past. The understanding of Salafi religion in Lombok arises because of the phenomenon of excessive taqlid given by the community to local religious leaders as described in the opinion of Tuan Guru Haji (TGH) Mahsun ${ }^{46}$ : ... The role of religious leaders (Tuan Guru) in the Muslim community in Lombok is generally still

${ }^{43}$ Muhammad Imarah, Thayyarat Al-Fikr al-Islam (Kairo: Dar al-Syuruq, 1995), p. 254.

${ }^{44}$ Muhammad Imarah, Thayyarat Al-Fikr al-Islam ..., p. 254.

${ }^{45}$ Interview with T.G.H. Mahsun in Midang Village on $22^{\text {nd }}$ December 2013.

${ }^{46}$ The Salafi figure from Midang Gunung Sari Village, West Lombok, has acted in religious teaching to the people in several places in Lombok. 
placed in a centralized position, where the community gives excessive authority to him. The community follows what the teacher says without wanting to look at the arguments (basis) of the law objectively... ${ }^{47}$

The Salafis do not want the addition or mixing of Islam and local cultural traditions. Because of this, they resist school fanaticism and reject imitation. According to TGH Said Husni, the pattern of understanding and disseminating religion (Islamic propagation) among the Muslim community in Lombok has not been completed. It is indicated through the religious pattern of the community that still accepts acculturation of local culture and traditions within their diverse behaviors. The rationale for their concept is based on the thought of Said bin Ali bin Wahab al-Qahthani, who said that the Shari'a had come perfectly. Therefore, there is no possibility of additions or deficiencies in it. The bid'ah makers were none other than trying to attack and destroy sharia or religion. They are some people who follow their passions. The argument is if the ratio does not follow the sharia, he will not have other thoughts unless he follows his lusts. ${ }^{48}$

To avoid all heretical acts and live according to the example of the Salaf al-Salih, the Salafi community chooses to strengthen its existence through interactions within their society, which is strongly bound between them by emphasizing living separately (exclusively) from society. This is done based on the assumption that the application of religious teachings adhered to by the local community has now undergone many changes and is contrary to Islamic teachings.

The Salafi community is active in organizing religious learnings for its members. The books commonly used in their learnings are: "Fath al-Majid" by Sheikh Abdurrahman bin Hasan bin Muhammad bin Abd Al-Wahhab, "Fath al-Majid" sharah "al-'Aqidah al-Shahabah volumes 1-2" by Imam al-Qodhi Ali bin 'Ali bin Abi al-'Izzi al-Dimasyqi, "Fiqh alAsma' al-Husna" by Abd al-Rozzak bin Abd al-Muhsin al-Badr, "Al-Wajiz fi Figh al -Sunnahi wa al-Kitabi al-'Azizi "by Dr. 'Abd al-Azhim bin

\footnotetext{
${ }^{47}$ Interview with TGH Mahsun in Midang Village on 22 ${ }^{\text {nd }}$ December 2013.

48 Said bin Ali bin Wahab Al-Qahthani, Cahaya Sunnah dan Sesatnya Bid'ah (Jakarta: Pustaka Azan, 2002), pp. 60-61.
} 
Badawi, "Zi al-Jalali wa al-Ikrami Syarh Bulug al-Marami" by al-Alammah Muhammad bin Sholeh al-Uthaimin, "Al-Zarkasyi' ala Mukhtasor alKharaqi" by Sheikh Syamsuddin bin Abdillah al-Zarkasyi al-Misri alHambali, and "Taudhih al-Ahkam Min Bulugi al-Marami" by Abdullah bin Abdirrahman bin Sholeh al Bassami.

The above books can be said to have become standard books for Salafis. TGH. Mahsun agrees with almost the same practice because everything is taken from one source. If there are anything different from the way of worship, daily practice, and opinions about the law, he has left the Salafi manhaj. Therefore, the Salafi group strictly avoids getting out of disagreement. ${ }^{49}$

\section{The Non-Salafi's Religious Thought}

Non-Salafi is a religious thought held by the majority of Muslims in Lombok, affiliated with the two largest Islamic organizations in Lombok, namely Nahdhatul 'Ulama' (NU) and Nahdhatul Wathan (NW). The existence of pesantren or majlis taklim led by Tuan Guru and Ustadz spread across the island of Lombok also shapes people's religious attitudes and views. According to Non-Salafis, preserving good traditions that develop in society is an important thing to do while bringing new things in a better way. So, local traditions and culture are placed in unison with religious values, as emphasized by TGH. Subki as-Sasaki: ${ }^{50} \ldots$ The teachings of Islam are spread by the masters of teachers to the community peacefully with a high spirit of tolerance towards the culture and cultural traditions of the people who previously embraced animism and dynamism. When teachers are invited to take fatwas on religious issues, they answer and direct them to the law (products) such as halal, haram, makruh, mubah, and sunnah without touching the methodology or how the law is formulated and enforced. They worry that explaining the methodology will cause people

\footnotetext{
${ }^{49}$ Interview with TGH Mahsun in Midang Village on 22 $2^{\text {nd }}$ December 2013.

${ }^{50}$ Subki As-Sasaki the most famous religious leader from Pelulan, West Lombok, the alumni of Al-Ishlahuddiny Islamic Boarding School, Kediri, West Lombok and Rubat al-Jufri, Madinah al-Munawarah. Today, he is very well known as the leader of Al-Madinah Islamic Boarding School and active in NU, West Nusa Tenggara.
} 
to fear converting to Islam because it will be difficult and hard." 51

Like the Salafis, other non-Salafis often carry out religious activities amid society, such as the Yasinan, the Serakalan al-Barzanji, and the Hiziban groups. The Hiziban group is part of the Hizb al-Nahdhatain recitation group with several activities such as the collection of Qur'anic verses, prayers, prayers, and poetry which are integrated by the founder of Nahdhatul Wathan (NW), namely TGH. Zainuddin Abdul Majid. ${ }^{52}$

In instilling faith and belief in the teachings of tauhid, teachers use Islamic books to develop the Islamic theology al-Asy'ariyah which was initiated by Abu al-Hasan al-Asy'ari. They use a number of references that are affiliated with al-Asy'ariyah theology such as: Umm al-Barahin by Abdullah Muhammad bin Yusuf al-Sanusi (ed. $895 \mathrm{H}$ ), which discusses the attributes of God and the characteristics of the messengers; Kifayat al-'Awwam written by Syeikh Muhammad al-Faddhali (died $1236 \mathrm{AH}$ ) which became the main reference in almost all pesantren in Lombok; Tijan al-Darary written by Sheikh Muhammad al-Nawawi al-Jawi, which is used for the interpretation of the book Tahqiq al-Maqam 'Ala Kifayat al-'Awwam which is one of the creed books most widely used as a reference by teachers who recites the Qur'an at Majlis Ta'lim in Lombok; Tuhfatul Murid by Sheikh Ibrahim al-Baijury which contains comments by Jauharah al-Tauhid by al-Laqqany (died $1041 \mathrm{AH}$ ); and Al-Hushun al-Hamidiyah written by Husain bin Muhammad al-Jasr al-Afandi alTarablusyi; The book of Perukunan Melayu written by Haji Abdul Rasyid

${ }^{51}$ Interview with TGH Subki al-Sasaki in Pelulan Village on $24^{\text {th }}$ December 2013.

${ }_{52}$ Tuan Guru Haji (TGH) Muhammad Zainuddin Abdul Majid, in Lombok society, he is familiarly called Tuan Guru Pancor, and some of them call him Mr. Maulana Syekh. He was born in Bermi Village, Pancor, on 17 Rabiul Awal 1316 H (1898 AD). He is the son of TGH Abdul Majid with Hajjah Halimatus Sadiyah. His father was known as a preacher and freedom fighter. The first name of Tuan Guru Pancor is Muhammad Saggaf. However, after completing the pilgrimage, his name was changed to Muhammad Zainuddin. This name was given by his father, which was taken from the name of a great scholar who taught at the Grand Mosque, namely Syekh Muhammad Zainuddin Sarawak. Upon his return from the Holy Land, Tuan Guru immediately founded the Al-Mujahidin Islamic Boarding School in 1934 AD. On 15 Jumadil Akhir 1356 H/22 August 1937 AD, the Nahdlatul Wathan Diniyah Islamiyah (NWDI) Madrasah was founded. Then, Madrasah Nahdlatul Banat Diniyah Islamiyah (NBDI) was founded on 15 Rabiul Akhir 1362 H / 21 April 1943 AD. In its development, Nahdlatul Wathan, which was founded in Pancor, East Lombok became the largest Islamic Mass Organization in NTB. 
al-Banjari which was taken from the writings of Syekh Muhammad al-Arsyad Banjar and Hidayat al-Salikin by Syekh Abdul Shamad alFalimbani. The last two books are written in Arabic-Malay and discuss faith, fiqh, and morals. Whereas in fiqh, they refer to several books, such as Khathib Syarbiny by Mugni al-Muhtaj, I'anatuth Thalibin, and Kifayatul Akhyar by Imam Taqiyuddin al-Dimasyqi, and others.

\section{Qath'i and Zhanni in Muslim Community's Perspectives}

There are various views on the concept of qath'i and zhanni among religious leaders in Lombok. Some of them classify religious texts into two types: first, postulates related to ushul (the core of religious teachings) such as matters of faith and belief, and second, the realm of furu '(branches of religious teachings) such as figh. Based on this classification, there is an opinion that there should be no disputes about ushul because it is qath' $i$ (definite). The difference of opinion can only matter in furu' because it is zhanni. According to TGH Mahsun, most of the legal arguments in the realm of fiqih (zaman'il fiqhiyah far'iyah) are zhanni, very few legal arguments in the form of qath'i. The law of qath'i is only related to fiqh issues for legal decisions that have been issued based on ulama's deliberation, such as the obligation of five daily prayers, fasting in the month of Ramadan, and others. In this context, TGH Said Husni emphasized that all legal arguments in the realm of tauhid (theology) are qath'i, including the interpretations of khabariyat (anthropomorphism) as contained in various letters and verses in the Qur'an. ${ }^{53}$.

On the other hand, M. Harfin Zuhdi ${ }^{54}$ tends to view these problems more academically. According to his opinion, the dichotomy between the issue of ushul (the core of Islamic teachings) and furu' (the branch of Islamic teachings) is an unknown problem in general. Zuhdi analyzed it factually, except for the qath'i issues because there were several differences in opinion among the Muslim scholars. The difference occurred in the

${ }^{53}$ Interview with TGH Said Husni in Pejarakan on $10^{\text {th }}$ December 2013.

${ }^{54}$ Lecturer at IAIN Mataram came from Panaraga Cakranegara Mataram, Alumni of UIN Syarif Hidayatullah Ciputat, active in recitating and teaching Islam in several places, and becomes the member of NU, West Nusa Tenggara. 
realm of furu' and ushul, meaning that the classification of ushul as a matter of faith and furu' as a non-faith problem that cannot be maintained..$^{55}$

Some Muslim scholars say that qath'i and zhanni are known as the conceptions and theories for a very limited circle, as introduced by the famous Muslim scholars and masters. In this regard, It can be said that the figure of the teachers or religious figures in the Lombok community plays a very central role. It means that the problems related to a linguistic theory like qath'i and zhanni are not generally themes conveyed in the community. TGH Aiman Az-Zahidi said that among the Muslim community in Lombok, the terms qathi and zhanni were not yet widely known even though they are always used in the implementation of legal stipulations. In daily religious practice, the people often imitate and follow what the master said without trying to find the legal argument of a problem until it produces objective knowledge. ${ }^{56}$

Several groups give other reasons that the level of fanaticism in society does not provide ample space for academic and objective discussion about a theory or concept. TGH Yudi Alfian said that the pattern of understanding of Muslims in Lombok is colored by high group fanaticism so that the application of the concepts of qathi $i$ and zhanni in various fields is not the main focus of their studies. ${ }^{57}$

Furthermore, it seems obvious that both the Salafis and the NonSalafis agree on the concepts of qath'i and zhanni, but they have different opinions regarding the areas of ushul and furu' as the variables that created qathi $i$ and zhanni. The indications of these differences appear in religious behavior and attitudes that are shown by the Salafis as they do not allow the difference in opinion and practices even though it is a matter of furu'.

In understanding the verse, scholars are divided into three groups, namely: first, the group that interprets it literally or textually; second, the group considers the verses to be metaphorical (figurative) so that these verses must be interpreted using the methods of majazi (parable) and

\footnotetext{
${ }^{55}$ Interview with M. Harfin Zuhdi, M.A in Mataram on $10^{\text {th }}$ December 2013.

${ }^{56}$ Interview with TGH Nurul Aiman Az-Zahidi, MA in Mataram in 22 ${ }^{\text {nd }}$ December 2013.

${ }^{57}$ Interview with TGH Yudi Alfian in Mataram on $25^{\text {th }}$ December 2013.
} 
ta'wil (illustration). For example, the Hand of Allah must be interpreted as the power of Allah, our eyes are under God's supervision, and the Face of God becomes God's self or substance, istiwa 'ala al-Arsy with power in His power; and third, the group that takes an intermediate position which asserts that God does have eyes, hands, and face, but how exactly the eyes, hands, and face of the human God will not know it with reason and will not be able to define it.

\section{The Implication of the Concept of Qath'i and Zhanni on Religious Behavior}

Theoretically, the Salafis and Non-Salafis agree in understanding qath'i and zhanni as legal instruments used to formulate Islamic law and to determine the level of legality and certainty of a legal problem both in the existence of figh and theology (tauhid). However, at the methodological level, they have different opinions and understandings. Such attitudes can be understood in their interpretation of the khabariyat (anthropomorphic characteristics) that are contained in various surahs in the al-Quran such as Yadullah (the Hand of Allah) in the QS Ali-Imran (3): 73, Qabdhathuhu (His grasp) in QS al-Zumar (39): 67, Bi a'yunina (with our eyes), Wajhu Rabbika (face of your Lord) in QS al-Rahman (55): 27, as well as Istawa 'ala al-Arsyi (He resides above the Throne) in QS. Thaha (25): 5.

In understanding the verse, scholars are divided into three groups, namely: The first group interprets it literally or textually; The second considers the verses to be metaphorical (figurative) so that these verses must be interpreted using the methods of majazi (parable) and ta'wil (illustration). For example, the Hand of Allah must be interpreted as the power of Allah, our eyes as under God's supervision, and the Face of God becomes God's self or substance, istiwa 'ala al-Arsy with power in His power, etc; the third takes an intermediate position which asserts that God does have eyes, hands, and face, but how exactly the eyes, hands, and face of God the human will not know it with reason and will not be able to define it. ${ }^{58}$

${ }^{58}$ Muhammad Imdad Robbani, 'Salafiyah: Sejarah dan Konsepsi', Tasfiyah: Jurnal Pemikiran Islam 1, Number 2 (2017): 267-68. 
Salafi groups, on the other hand, tend to understand this khabariyat (anthropomorphic characteristics) verses textually. They relied on the opinion of Imam Malik who stated that sitting on a throne is something that is known, whereas how God sits cannot be known, and inquiring about Him is bid'ah. Likewise, with some fiqh issues related to the practice of worship rituals, there are also differences of opinion such as in tablilan (prayer for the death), talkin (recitation in the grave for the deceased), $d z i k r$ in a loud voice after congregational prayer, dress code (restrictions procedures for using the sarongs and pants), qunut in the second raka'ah at Fajr prayer, and so on.

The difference in the issue of fiqh cannot be avoided because the character of the legal arguments contained in the Quran and the Hadith does not stipulate the law. On the other hand, in this context, 'aql or ratio plays an active role in formulating and establishing the laws that are not stipulated in the texts of the Quran and the Hadith. As emphasized by Abdul Wahab Khallaf, all the texts of the Quran and the Hadiths of Mutawatir are qath 'i al-wurûd wa al-tsubut (definite in its existence and revelation), but the designation of their meaning towards the law does not have the same power; some are qath' $i$ al-dalalah (definite in meaning) and zhanni al-dalalah (indefinite/interpretable in meaning). ${ }^{59}$

In responding to these differences, the Muslim scholars put forward several limitations: first, the differences of opinion did not touch the core of Islamic teachings. In other words, this difference must not relate to the issue of the Oneness of God, the testimony that the Prophet Muhammad SAW as the Messenger of Allah, the revelation of the Quran from Allah, and the Quran is the greatest miracle and so on. Besides, the difference is not also about the principal duties such as prayer, zakat, hajj, and fasting, nor it is about how to perform them. ${ }^{60}$

${ }^{99}$ Abdul Wahab Khallaf, Mashâdir Al-Tasyrî 'al-Islâmi Fîmâ Lâ Nassha Fîhâ, 5th edn (Kairo: Dar al-Qalam, 1402), p. 18.

${ }^{60}$ Muhammad Abu Zahrah, Aliran Politik dan Aqidah dalam Islam (Jakarta: Logos Publishing House, 1996), p. 5. 
Regarding socio-religious practices performed by the Muslim community in Lombok such as belangar (attending the death events), nelung (commemorating the three days of death), mitu' (commemorating the seven days of death), and nyiwa' (commemorating the nine days of death), such practices emerged because of the process of acculturation and the contact of local culture with Islamic teachings. There is no clear evidence or legal basis in the Quran and the Hadith. Thus the acceptance of the law in all these issues depends on the extent to which the values of benefit and utility are achieved. TGH Subki al-Sasaki said that the local traditions and culture of the community as long as they do not conflict with Islamic teachings can be a legal argument that is qath'i as the texts of the Quran and the Hadith. In other words, al-urf or 'adat (tradition) may become an important instrument in the issues not stipulated in the Quran and the Hadith when they have values of benefit and utility that can be achieved and not against religion. ${ }^{61}$

According to the Salafis, all these religious practices are issues that have never been practiced by Rasulullah SAW. They are not textually guided in the texts of the Quran and the Hadith but merely based on the reason, thus, they do not have a legal basis and foundation directly from the Messenger of Allah. Therefore, the Salafis group considers them as the heretical acts whose legal implication is haram to be practiced. The Salafis also divide the Islamic teachings into two aspects, such as ushul (the core of religious teachings) and furu' (branches of religious teachings). The socio-religious practices as mentioned above are related to the belief (ushul). Thus, the Salafis only consider them to be the qath'i arguments that cannot be contested. It is different from the Non-Salafis who consider the socio-religious practice to be debatable, therefore it is included in the zhanni category.

\section{Conclusion}

Referring to the explanation above, it can be concluded that the Salafi and Non-Salafi communities agree on qath' $i$ as a conception

${ }^{61}$ Interview with TGH Subki Al-Sasaki in Pelulan Village on $24^{\text {th }}$ December 2013. 
that cannot be contested, while zhanni is not the case. The existence of methodological differences in identifying qath $i$ and zhanni areas has implications on their religious behaviors. Through using a textual approach and ignoring the contextual approach, the Salafis consider laws that are still in the debatable categorized into qath'i. This tendency is different from Non-Salafis who use textual and contextual approaches to conclude that the laws identified in the debatable area are zhanni.

The different approaches used by Muslim scholars and academicians in understanding Islamic law result in a tendency in the Salafi community to rely on the textual understanding that leads to narrow or "dwarf" Islamic law. Understanding the religion as a whole is not enough through standing on textual understanding because this will distance Islamic teachings from the core and substance of the purpose of religious practice. Besides, contextual understanding is also very important because it relates to the differences in space and time between the problems faced by Muslims today and the situation when the text of the Qur'an was revealed to the Prophet Muhammad SAW.

\section{Bibliography}

Abd Razak, Muhd Imran, Rahimin Affandi Abd Rahim, Mohd Anuar Ramli, and Nurul Hidayah Abd Aziz, 'Salafi Jihad's Version and Coercion to World Peace: An Islamic Educational Perspective', International Journal of Academic Research in Business and Social Sciences, 7.12 (2017), 1265-80

Abu Zahrah, Muhammad, Aliran Politik dan Aqidah dalam Islam (Jakarta: Logos Publishing House, 1996)

Ahmad, Laode Ismail, and Syamsidar, 'Rekonstruksi Teks-Teks Hukum

Qath'I dan Teks-Teks Hukum Zhanni; Meretas Jalan Menuju Pendekatan Tekstual-Kontekstual', Asy-Syir'ah; Jurnal Ilmu Syariah Dan Hukum, 49.2 (2015), 230-50

al-Ashfahani, Al-Ragib, Al-Mufradât Fî̀ Garîb al-Qur'ân, 1st edn (Damaskus: Dar al-Qalam, 1412), I

Al-Qahthani, Said bin Ali bin Wahab, Cahaya Sunnah dan Sesatnya Bid'ah (Jakarta: Pustaka Azan, 2002) 
Al-Razi, Fakhruddin, Al-Mahshul Fi Ilmi al-Ushul, 2nd edn (Beirut: Dar al-Kutub al-Ilmiyah, 1408)

Ancok, Djamaludin, and Fuad Nashori Suroso, Psikologi Islam: Solusi Islam Atas Problem-Problem Psikologi (Yogyakarta: Pustaka Pelajar, 2004)

Anonim, 'The Attack of Salafi Group into Mesanggok Village Gerung District.', Tabloid Perspektif, 1 March 2009

Antunez, Juan Carlos, 'Salafism: From a Religious Movement to a Political Force', Revista de Estudios En Seguridad Internacional, 3.1 (2017), $11-42$

Arifin, Asep, 'Aplikasi Dalil Qath'I dan Zhanni Dalam Pertimbangan Subyek Dan Tujuan Hukum', Jurnal Ahkam, 13.1 (2013), 89-98 Arkoun, Mohammad, The Politics of Islamic Revivalism (Editor) Shireen T. Hunter (Bloongton: Indiana University Press, 1988)

Assegaf, Abd Rachman, 'Gerakan Transnasional Islam dan Globalisasi Salafi di Islamic Center Bin Baz Yogyakarta', Millah: Jurnal Studi Agama, 0.2 (2017), 147-72 <https://doi.org/10.20885/millah.vol16. iss 2.art $1>$

Cholifah, Umi, 'Membumikan Qath'I Dan Zhanni; Konsep Absolut Dan Relativitas Hukum', Jurnal An-Nuha, 4.2 (2017), 141-47

Faisal, Sanafiah, Penelitian Kualitatif: Dasar-Dasar dan Aplikasi (Malang: YA3, 1990)

Faizah, Faizah, 'Pergulatan Teologi Salafi Dalam Mainstream Keberagamaan Masyarakat Sasak', Jurnal Ulumuna IAIN Mataram, 16.2 (2012), $375-402$

al-Gazali, Abu Hamid, Al-Mankhul Fi Ta'liqat al-Ushul (Beirut: Dar al-Fikr, 1400)

Gumanti, Retna, 'Maqasid Al-Syariah Menurut Jasser Auda: Pendekatan Sistem dalam Hukum Islam', Jurnal Al-Himayah, 2.1 (2018), 97-118 Haika, Ratu, 'Konsep Qath'I Dan Zhanni Dalam Hukum Kewarisan Islam', Jurnal Mazahib, 15.2 (2016), 183-95

Ibnu Asyur, Muhammad Tahir, Maqashid Al-Syariah Al-Islamiyah (Kairo dan Beirut: Dar al-Kitab al-Mishri dan Dar al-Kitab al-Lubnani, 2011) 
Ibnu Faris, Ibnu Faris, Mu’jam Maqâyîs Al-Lugah, 2nd edn (Kairo: Mushthafa al-Babi al-Halabi, 1971), v

Imarah, Muhammad, Thayyarat Al-Fikr al-Islam (Kairo: Dar al-Syuruq, 1995)

Khallaf, Abdul Wahab, Mashâdir Al-Tasyrî 'al-Islâmi Fîmâ Lâ Nassha Fîhâ, 5th edn (Kairo: Dar al-Qalam, 1402)

Mufid, Moh., 'Qath'i Dan Zhanni dalam Pemikiran Islam; Memahami Teks dan Konteks Secara Proporsional', Jurnal Al Hikmah, 15.2 (2014), 232-50

Muslim, Muslim, 'Qath'i-Zhanni Al-Syathibi dalam Pembentukan Hukum Islam', Jurnal Wasathiyah, 2.1 (2018), 97-108

Nadia, Zunly, 'Perilaku Keagamaan Komunitas Muslim di Indonesia: Pemahaman Hadis dalam NU dan Komunitas Salafi Wahabi di Indonesia', JURNAL LIVING HADIS, 2.2 (2017), 141-77

Nashirudin, Muh, 'Interaksi Simbolis Pondok Pesantren Salafi dan Masyarakat', Epistemé: Jurnal Pengembangan Ilmu Keislaman, 12.1 (2017), 141-67 <https://doi.org/10.21274/epis.2017.12.1.141-167> al-Qarafi, Syihabuddin, Syarh Tanqîh Al-Fushûll (Beirut: Dar al-Fikr, 2014) Robbani, Muhammad Imdad, 'Salafiyah: Sejarah dan Konsepsi', TASFIYAH: Jurnal Pemikiran Islam, 1.2 (2017), 245-76

Romli SA, Romli SA, 'Konsep Qath'iy-Zhanniy Serta Implikasinya dalam Istinbath Hukum', Jurnal Intizar, 21.1 (2015), 147-63

Saada, Najwan, 'The Theology of Islamic Education from Salafi and Liberal Perspectives', The Official Journal of the Religious Education Association, 2018, 1-13 <https://doi.org/DOI: 10.1080/00344087.2018.1450607> Sadan, Saifuddin, 'Ijtihad Terhadap Dalil Qath'i Dalam Kajian Hukum Islam', Samarah: Jurnal Hukum Keluarga dan Hukum Islam, 1.2 (2017), 479-90

Saed, Abdullah, Islamic Tought An Introduction (London and New York: Routledge, 2006)

al-Samarkandi, 'Alauddin, Mîzan Al-Ushîl Fî̀ Natâ'ij al-'Uqûl, 2nd edn (Kairo: Dar al-Turats, 1997) 
Saparudin, Saparudin, and Emawati, Masjid dan Fragmentasi Sosial: Pencarian Eksistensi Salafi Di Tengah Mainstream Islam Di Lombok, Laporan Penelitian 2018 (Mataram: LP2M UIN Mataram), Hal. 24 (Mataram: LP2M UIN Mataram, 2018), pp. 1-81

Suriasumantri, Jujun S, Penelitian Ilmiah, Kefilsafatan, dan Keagamaan: Mencari Paradigm Kebersamaan" Dalam Deden Ridwan (Ed). Tradisi Baru Penelitian Agama Islam Tinjauan Antar Disiplin Ilmu (Bandung: Penerbit Nuansa, 2011)

al-Syairazi, Abu Ishaq, Al-Luma' Fî Ushûl al-Fiqh, 3rd edn (Kairo: Mushthafa al-Babi al-Halabi, 1377)

al-Syathibi, Abu Ishak, Al-Muwafaqat Fi Ushul al-Syariah (Beirut: Dar al-Kutub al-Ilmiyah)

al-Taftazani, Sa'duddin, Syarh Al-Talwîh 'Ala al-Taudlîh (Beirut: Dar al-Fikr, 1424), I

Ubaidillah, Ubaidillah, 'Global Islam Dan Pengaruhnya di Indonesia', Jurnal Thaqafiyyat, 13.1 (2012), 35-48

Interview with TGH Mahsun in Midang, West Lombok in 22 $2^{\text {nd }}$ December 2013.

Interview with TGH Said Husni in Pejarakan on 10 th $^{\text {th }}$ December 2013. Interview with TGH Subki Aal-Sasaki in Pelulan, West Lombok in $24^{\text {th }}$ December 2013.

Interview with Ustadz Nurul Aiman Az-Zahidi, MA in Mataram in $22^{\text {nd }}$ December 2013.

Interview with Ustadz Yudi Alfian in Mataram in 25 Interview with Ustadz M. Harfin Zuhdi, M.A in Mataram in $10^{\text {th }}$ December 2013. 